\title{
Preparation of Chitosan Coated Magnetic Hydroxyapatite Nanoparticles and Application for Adsorption of Reactive Blue 19 and $\mathrm{Ni}^{2+}$ Ions
}

\author{
Van Cuong Nguyen and Quoc Hue Pho \\ Department of Chemical Engineering, Industrial University of Ho Chi Minh City, 12 Nguyen Van Bao Street, Go Vap, \\ Ho Chi Minh City 70000, Vietnam
}

Correspondence should be addressed to Van Cuong Nguyen; nvc@hui.edu.vn

Received 31 August 2013; Accepted 28 November 2013; Published 2 February 2014

Academic Editors: K. Z. Elwakeel and D. Fu

Copyright (C) 2014 V. C. Nguyen and Q. H. Pho. This is an open access article distributed under the Creative Commons Attribution License, which permits unrestricted use, distribution, and reproduction in any medium, provided the original work is properly cited.

\begin{abstract}
An adsorbent called chitosan coated magnetic hydroxyapatite nanoparticles (CS-MHAP) was prepared with the purpose of improvement for the removal of $\mathrm{Ni}^{2+}$ ions and textile dye by coprecipitation. Structure and properties of CS-MHAP were characterized by scanning electron microscopy (SEM), X-ray diffraction (XRD), Fourier transform infrared spectroscopy (FTIR), and vibrating sample magnetometer (VSM). Weight percent of chitosan was investigated by thermal gravimetric analysis (TGA). The prepared CS-MHAP presents a significant improvement on the removal efficiency of $\mathrm{Ni}^{2+}$ ions and reactive blue 19 dye (RB19) in comparison with chitosan and magnetic hydroxyapatite nanoparticles. Moreover, the adsorption capacities were affected by several parameters such as contact time, initial concentration, adsorbent dosage, and initial $\mathrm{pH}$. Interestingly, the prepared adsorbent could be easily recycled from an aqueous solution by an external magnet and reused for adsorption with high removal efficiency.
\end{abstract}

\section{Introduction}

Water that contains heavy metals and dye wastes represents one of the most problematic pollution groups because it can cause serious threat to human beings, animals, and plants. The wastewater was discharged from several industrial actives such as plating, metallurgy, and dyeing. Dyestuffs and pigments are popularly used in different fields in industries such as textile, paper, rubber, plastic, leather, cosmetics, food, and drug. The synthetic dyes and pigments are toxic, nonbiodegradable, and carcinogenic due to aromatic rings in the structures. Additionally, heavy metals such as $\mathrm{Ni}^{2+}$ and $\mathrm{Cu}^{2+}$ ions are known to be essential trace metals to human beings but high intake of $\mathrm{Ni}^{2+}$ and $\mathrm{Cu}^{2+}$ ions can also cause health problems like gastrointestinal disturbance, liver impaired failure, and kidney failure. However, it is not easy to treat the wastewater of dyes and heavy metals to become harmless to human and media surroundings $[1,2]$. Recently, problems of removing dyes and heavy metals from wastewater in the industry have been becoming an important and significant field in wastewater treatment. There are many wastewater treatment methods used for dyes and heavy metals removal from wastewater $[3,4]$ : chemical treatment [5], biological method [6], physicochemical method [7], electrochemical process [8], adsorption [9], and photocatalytic degradation [10]. One of these methods called the adsorption method has become one of the most effective and feasible technique. In the adsorption technique, activated carbon has been reported to be the most effective material but is an expensive material and its use for applications of pollution control cannot be justified [11, 12]. Therefore, tendencies to use materials that are natural, biodegradable, cheap, renewable, and environmentally-friendly were supported to research by experts.

Recently, chitosan (CS) has been known as a novel biomaterial that scientists pay attention to. It has been described as a nontoxic, biodegradable, and biocompatible polymer with very interesting biological properties such as wound 
dressing, drug delivery systems, and tissue engineering [13-15]. However, chitosan has unexpected properties that makes itself become limited to use for adsorption such as poor mechanical strength, low specific gravity, easy agglomeration, or gel formation, and insufficient solubility in dilute acids largely limits its widespread applications for environmental pollutant removal $[16,17]$. Therefore, chitosan is often used to combine with other materials to improve their unexpected properties. To pave the way for using CS for hazardous metals and dyes removals, several attempts have been made to improve the mechanical strength and adsorption efficiency by immobilization of CS on rigid inorganic materials. Hydroxyapatite $\left[\mathrm{Ca}_{10}\left(\mathrm{PO}_{4}\right)_{6}(\mathrm{OH})_{2}, \mathrm{HAP}\right]$, a very well-known material in bones and teeth, is combined with chitosan to create a novel composite that ameliorates properties of chitosan and is applied in biological and medical fields such as implant coating and bone tissue engineering $[18,19]$. In addition, hydroxyapatite has a porous structure that makes it become widely used as an adsorbent for removal of heavy metals and dyes.

Applications of combining chitosan with hydroxyapatite as a novel, powerful material for adsorption have been reported in previous article [20, 21]. However, previous materials were not to be used popularly in industries due to its impossibility of renewal. Therefore, in this study the material was ameliorated by adding magnetic nanoparticles $\left(\mathrm{Fe}_{3} \mathrm{O}_{4}\right)$ into the composite of chitosan and hydroxyapatites with the purpose of increasing their usage effectiveness through the magnetic separation. In this study, we propose to synthesize the magnetic composite of chitosan and hydroxyapatite and explore the possibility of using prepared magnetic composite as an adsorbent for the removal of organic textile dyes and heavy metals from aqueous solutions.

\section{Materials and Methods}

2.1. Materials. Chitosan (90\% deacetylation) was prepared in our lab. Reactive blue 19 (RB19) was donated by Thanh Cong Textile Company. All chemicals were analytical grade and used without further purification and all solutions were prepared with deionized water.

\subsection{Preparation of Magnetic Hydroxyapatite Nanoparticles} (MHAP). In this study, the MHAP material was synthesized by coprecipitation method according to the previous report with some modification [22]. First, $\mathrm{FeCl}_{2} \cdot 4 \mathrm{H}_{2} \mathrm{O}$ and $\mathrm{FeCl}_{3} \cdot 6 \mathrm{H}_{2} \mathrm{O}$ salts were used in the molar ratio $2: 1$. In brief, determined amounts of $\mathrm{FeCl}_{2} \cdot 4 \mathrm{H}_{2} \mathrm{O}(1.85 \mathrm{mmol})$ and $\mathrm{FeCl}_{3} \cdot 6 \mathrm{H}_{2} \mathrm{O}(3.7 \mathrm{mmol})$ were dissolved in $30 \mathrm{~mL}$ of deoxygenated water under a nitrogen atmosphere at room temperature then $10 \mathrm{~mL}$ of $25 \% \mathrm{NH}_{4} \mathrm{OH}$ solution were added to the resulting solution under a magnetic stirrer $(3000 \mathrm{rpm})$ for $15 \mathrm{~min}$. Then, $\mathrm{Ca}\left(\mathrm{NO}_{3}\right)_{2} \cdot 4 \mathrm{H}_{2} \mathrm{O}(33.7 \mathrm{mmol})$ and $\left(\mathrm{NH}_{4}\right)_{2} \mathrm{HPO}_{4} \cdot 4 \mathrm{H}_{2} \mathrm{O}(20 \mathrm{mmol})$ dissolved in $50 \mathrm{~mL}$ water and were added to the previously mentioned solution, then the $\mathrm{pH}$ of the resulting solution was adjusted to 11 . The precipitation was formed simultaneously and stirred for $30 \mathrm{~min}$ at room temperature and increased to $90^{\circ} \mathrm{C}$ for $2 \mathrm{hr}$.
The mixture was cooled to room temperature and aged for $12-$ $24 \mathrm{~h}$ without stirring. The obtained precipitate was separated by a magnet, washed repeatedly with deionized water until neutrality, then dried in a drying oven at $90^{\circ} \mathrm{C}$, and grinded with mortar.

\subsection{Preparation of Chitosan Coated Magnetic Hydroxyapatite} Nanoparticles (CS-MHAP). In order to coat chitosan onto surface of MHAP, chitosan reacted with glutaraldehyde to cross-link bonds $[23,24]$. An appropriate amount of chitosan $(1.25 \mathrm{~g}$ ) was dissolved in $125 \mathrm{~mL}$ acetic acid (1\%) in a $500 \mathrm{~mL}$ beaker containing an amount of the as-prepared MHAP. The mixed solution was stirred continuously for $1 \mathrm{~h}$ in order to disperse regularly MHAP in chitosan solution. Then, $0.5 \mathrm{~mL}$ glutaraldehyde $25 \%$ was added into the mixture to form gel. After completion of the reaction, the $\mathrm{pH}$ in the system was adjusted to 9 using $2 \mathrm{M} \mathrm{NaOH}$ solution. The mixture was stirred and heated on a water bath for $3 \mathrm{~h}$ at $60^{\circ} \mathrm{C}$. The magnetic beads were formed and washed with acetone and distilled water. Finally, the CS-MHAP materials were dried at $80^{\circ} \mathrm{C}$.

2.4. Characterization. An X-ray diffraction was carried out in X'Pert Pro MRD (PANanalytical, The Netherlands) at room temperature with $\mathrm{Cu}-\mathrm{K} \alpha$ radiation $(\lambda=0.154 \mathrm{~nm})$ and an incident angle $(2 \theta)$, ramping from 2 to $80^{\circ}$ at a rate of 50 seconds/step. Magnetic measurement of the product was conducted on a vibrating sample magnetometer (VSM-5 Model, MicroSense Co., Ltd.). Scanning Electron Microscope (SEM) and Fourier transform infrared spectroscopy (FTIR) were used to characterize the morphology and structure of prepared material.

2.5. Adsorption of Reactive Blue 19 Experiments. 0.1g CSMHAP composite was added into $50 \mathrm{~mL}$ RB19 solution with different initial concentrations $\left(50,75,100\right.$, and $\left.150 \mathrm{mg} \mathrm{L}^{-1}\right)$. A stirrer was used to mix the solutions. The samples from suspension were separated by a permanent magnet. Concentration of samples was determined using a UV-Vis spectrophotometer at $\lambda=592 \mathrm{~nm}$.

2.5.1. Effect of Contact Time and Initial Concentration. The effect of equilibration of adsorbents was studied in different time intervals ranging from 10 to $240 \mathrm{~min}$ with initial RB19 concentrations of $50,75,100$, and $150 \mathrm{mg} \cdot \mathrm{L}^{-1}$. The aqueous samples were taken at determined intervals and the concentrations of dye were measured at $592 \mathrm{~nm}$, using UV-Vis spectrophotometer. Adsorptive efficiency of CS-MHAP and equilibrium adsorption capacity $q_{e}\left(\mathrm{mg} \cdot \mathrm{g}^{-1}\right)$ were calculated as follows [25]:

$$
\begin{gathered}
R=\frac{\left(C_{0}-C_{e}\right)}{C_{0}} \times 100 \%, \\
q_{e}=\frac{\left(C_{0}-C_{e}\right) \times V}{m},
\end{gathered}
$$




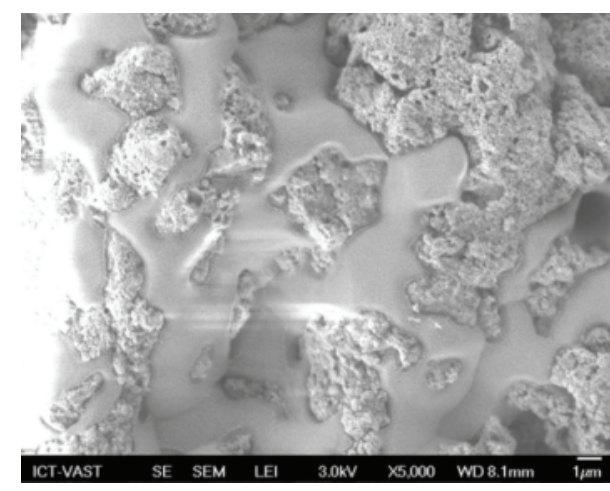

(a)

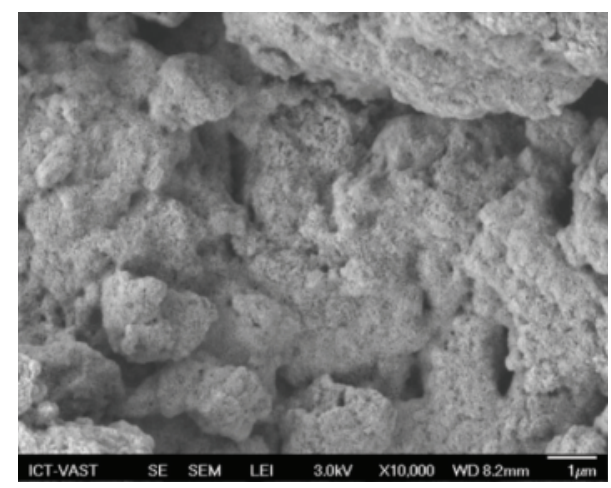

(b)

Figure 1: SEM images of prepared CS-MHAP (a) 5000× and (b) 10000×.

where $C_{0}$ and $C_{e}$ are the initial and equilibrium concentration $\left(\mathrm{mg} \cdot \mathrm{L}^{-1}\right)$, respectively, $m$ is dosage of CS-MHAP $(\mathrm{mg})$, and $V$ is volume of solution (L).

2.5.2. Effect of CS-MHAP Dosage. Different amounts of CSMHAP ( 0.025 to $0.1 \mathrm{~g} ; 0.5$ to $\left.2 \mathrm{~g} \mathrm{~L}^{-1}\right)$ and $50 \mathrm{~mL}$ of $50 \mathrm{mg} \mathrm{L}^{-1}$ RB19 solutions were placed in a $100 \mathrm{~mL}$ beaker and stirred regularly in different time intervals. After separation, the concentrations of dye in the solutions were determined.

2.5.3. Effect of $p H$ Solution. For the same initial concentration, equilibration time and adsorbent amount were investigated as a function of $\mathrm{pH}$. The initial $\mathrm{pH}$ values were adjusted $4,6,8,10$, and 12 using $0.1 \mathrm{M} \mathrm{HCl}$ or $0.1 \mathrm{M} \mathrm{NaOH}$ solution. After equilibration time, the suspensions were separated and the residual RB19 concentrations were measured.

2.6. Adsorption of $\mathrm{Ni}^{2+}$ Ions Experiments. Stock solutions $\left(1000 \mathrm{mg} \mathrm{L}^{-1}\right)$ of $\mathrm{Ni}^{2+}$ were prepared for adsorption experiments. The solutions of different concentrations used in various experiments were obtained by dilution of the stock solutions. $0.5 \mathrm{~g}$ CS-MHAP was added into the $50 \mathrm{~mL} \mathrm{Ni}^{2+}$ solution with various initial concentrations. The reaction solution was mixed by a stirrer. The samples from the suspension were collected at regular intervals of time, separated by a permanent magnet. Concentrations of samples of $\mathrm{Ni}^{2+}$ ion were determined by using standard methods recommended for examination of water and wastewater [26]. Adsorption efficiency of CS-MHAP and equilibrium adsorption capacity $q_{e}\left(\mathrm{mg} \mathrm{g}^{-1}\right)$ were calculated as follows (1). The amount of adsorption at time $t, q_{t}(\mathrm{mg} / \mathrm{g})$, is calculated by $q_{t}=$ $\left(C_{0}-C_{t}\right) * V / W$ where $C_{0}$ and $C_{t}(\mathrm{mg} / \mathrm{L})$ are the liquidphase concentrations of $\mathrm{Ni}^{2+}$ ions at initial and any time $t$, respectively; $V$ is the volume of the solution $(\mathrm{L}) ; W$ is the mass of dry adsorbent used (g).

2.6.1. Effect of Contact Time and Initial Concentration. The effect of contact time on each metal sorption was studied in different time intervals ranging from $30 \mathrm{~min}$ to $6 \mathrm{~h}$ with $25,50,75$, and $100 \mathrm{~m} \mathrm{~L}^{-1}$ initial metal concentrations. After the completion of the reaction, the CS-MHAP adsorbents were separated by a permanent magnet. Residual concentrations of $\mathrm{Ni}^{2+}$ ions were determined.

2.6.2. Effect of CS-MHAP Dosage. Different amounts of MNHAP-CS $\left(0.1\right.$ to $0.5 \mathrm{~g} ; 2$ to $10 \mathrm{~g} \mathrm{~L}^{-1}$ ) and $50 \mathrm{~mL}$ of $50 \mathrm{mg} \mathrm{L}^{-1}$ metal solutions were placed in $100 \mathrm{~mL}$ beakers and stirred regularly in different time intervals. After separation, the final concentrations of $\mathrm{Ni}^{2+}$ in the solutions were measured.

2.6.3. Effect of $\mathrm{pH}$ Solution. The effect of $\mathrm{pH}$ on the adsorption of $\mathrm{Ni}^{2+}$ ions was examined by mixing $0.5 \mathrm{~g}$ composite with $50 \mathrm{~mL}$ of $\mathrm{Ni}^{2+}$ ions solution $\left(50 \mathrm{mg} \mathrm{L}^{-1}\right)$, equilibrium time $240 \mathrm{~min}$, and the $\mathrm{pH}$ ranging from 4 to 7 . The initial $\mathrm{pH}$ values were adjusted from 4 to 8 , using $0.1 \mathrm{M} \mathrm{HCl}$ or $0.1 \mathrm{M}$ $\mathrm{NaOH}$ solution. After equilibration time, the suspensions were separated and the residual metal concentrations were analyzed.

\section{Results and Discussion}

3.1. Properties of Prepared CS-MHAP Adsorbent. The scanning electron microscope (SEM) micrograph of CS-MHAP is shown in Figure 1. The result of SEM micrograph shows that composite surface is rough and has porous structure with holes and small openings on the surface, resulting in this prepared material which has a good adsorption capacity. The homogeneously distributed pore structure of MHAP nanoparticles was indicated in Figure 1(a) also supported by the high porosity and high open pore content. The microstructure obtained by SEM (Figure 1(b)) for CS-MHAP composite prepared by gel-formation showed that the MHAP nanoparticles are relatively dispersed in the chitosan matrix. As shown in Figure 1, the MHAP material has two different solid phases meaning that there is a phase of magnetic and another phase of hydroxyapatite.

The FTIR graphs of CS-MHAP and MHAP are shown in Figure 2. As can be seen, the adsorption bands at around 


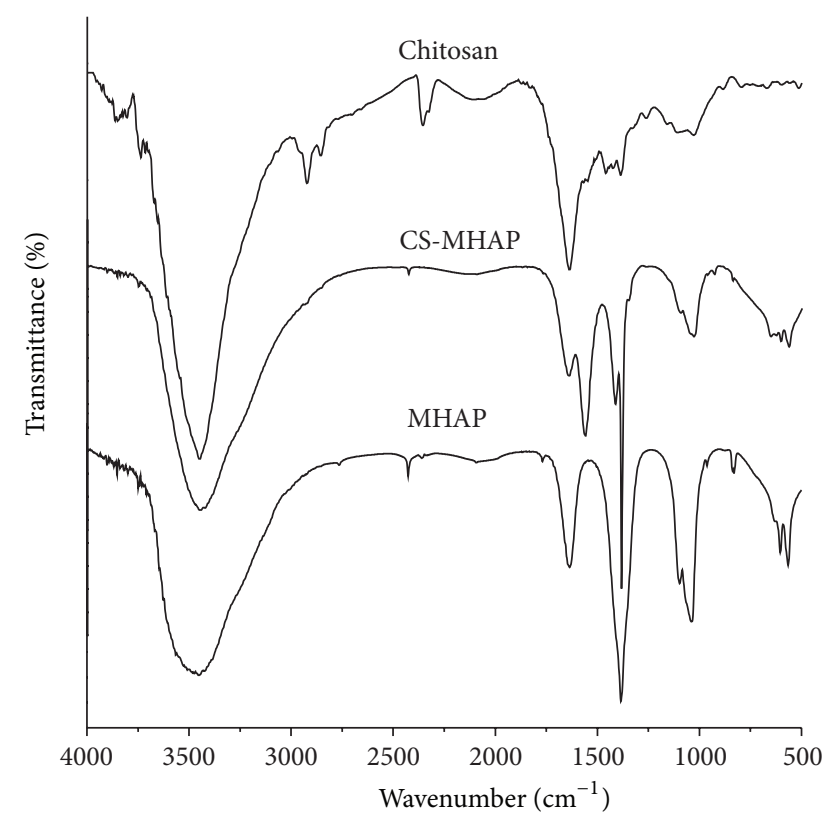

FIGURE 2: FTIR spectrum of prepared materials chitosan, CSMHAP, and MHAP.

$618 \mathrm{~cm}^{-1}$ correspond to the stretching and vibration of the lattice $\mathrm{OH}^{-}$ions, while the bands of adsorbed water are shown at $3445.79 \mathrm{~cm}^{-1}$ and $1635.92 \mathrm{~cm}^{-1}$. The characteristic bands for $\mathrm{PO}_{4}{ }^{3-}$ represented at $560 \mathrm{~cm}^{-1}$ and $1096.64 \mathrm{~cm}^{-1}$. Moreover, several typical bands were assigned for existence of chitosan in structure of the CS-MHAP. The characteristic absorption bands appeared at around $3445 \mathrm{~cm}^{-1}$ corresponding to the stretching vibration of $\mathrm{O}-\mathrm{H}$ and $\mathrm{N}-\mathrm{H}$ bonds. The peaks at $2923 \mathrm{~cm}^{-1}, 1641 \mathrm{~cm}^{-1}, 1388 \mathrm{~cm}^{-1}$, and $1029 \mathrm{~cm}^{-1}$ are ascribed to $\mathrm{C}-\mathrm{H}$ of alkyl group, $\mathrm{C}=\mathrm{O}$ of amide $\mathrm{I},-\mathrm{NHCO}$ of amide III, and $\mathrm{C}-\mathrm{OH}$ bond, respectively. The absorption peak of chitosan at $1560 \mathrm{~cm}^{-1}$ was assigned to the characteristic peak of $\mathrm{NH}_{2}$, while this peak was shifted to $1597 \mathrm{~cm}^{-1}$ in the composite. The appearance of new peak at $1597 \mathrm{~cm}^{-1}$ in FTIR was related to the vibrations of protonated amine groups [27].

The XRD patterns of chitosan, MHAP, and CS-MHAP were shown in Figure 3. The straight base line and the not sharp peaks of the diffractogram confirmed that the CSMHAP was not well crystallized as the MHAP due to the representation of chitosan coated on the surface of MHAP. Figure 3 also represents the peaks at $2 \theta$ of $25.8^{\circ}, 31.8^{\circ}, 32.1^{\circ}$, $32.9^{\circ}, 34^{\circ}, 39.9^{\circ}, 46.7^{\circ}$, and $49.4^{\circ}$ for the existence of HA in the CS-MHAP. The peaks at $2 \theta$ of $10.02^{\circ}, 19.8^{\circ}$, and $21.9^{\circ}$ indicate that chitosan is coated on MHAP. Furthermore, the peaks at $2 \theta$ of $30^{\circ}, 35.5^{\circ}$, and $63^{\circ}$ are typical peaks for representation of $\mathrm{Fe}_{3} \mathrm{O}_{4}$ in the CS-MHAP. A similar assignment was reported previously [27].

The thermogravimetric analysis (TGA) (Figure 4) was carried out in air at a heating rate of $10^{\circ} \mathrm{C} / \mathrm{min}$ [28]. As can be seen, there are two characterized curves for the thermogravimetric analysis. These curves are the TG and DSC curves. The TG curve of CS-MHAP shows that the weight loss over temperature from 35 to $800^{\circ} \mathrm{C}$ was about $28 \%$

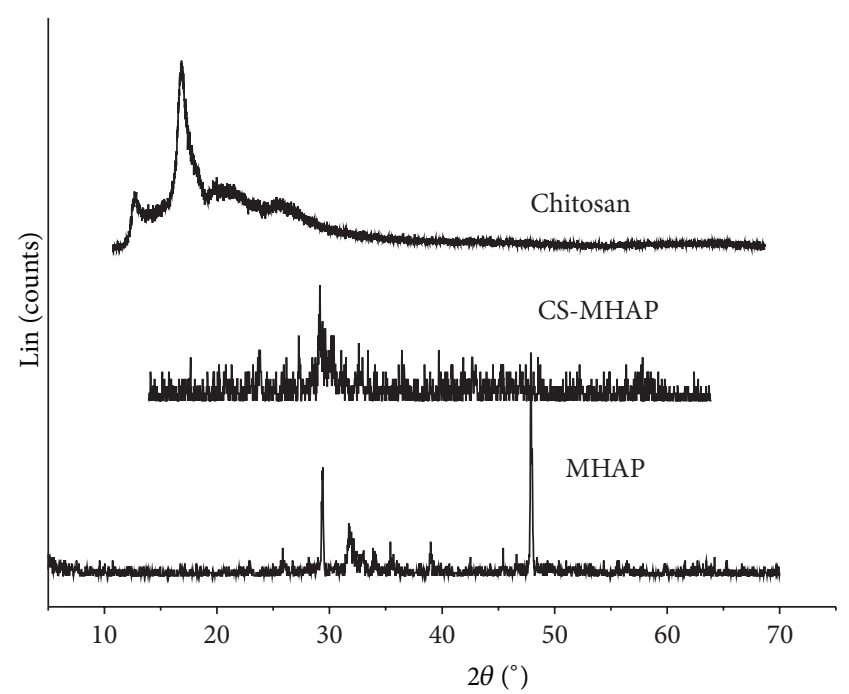

FIGURE 3: X-ray diffraction (XRD) pattern of prepared materials.

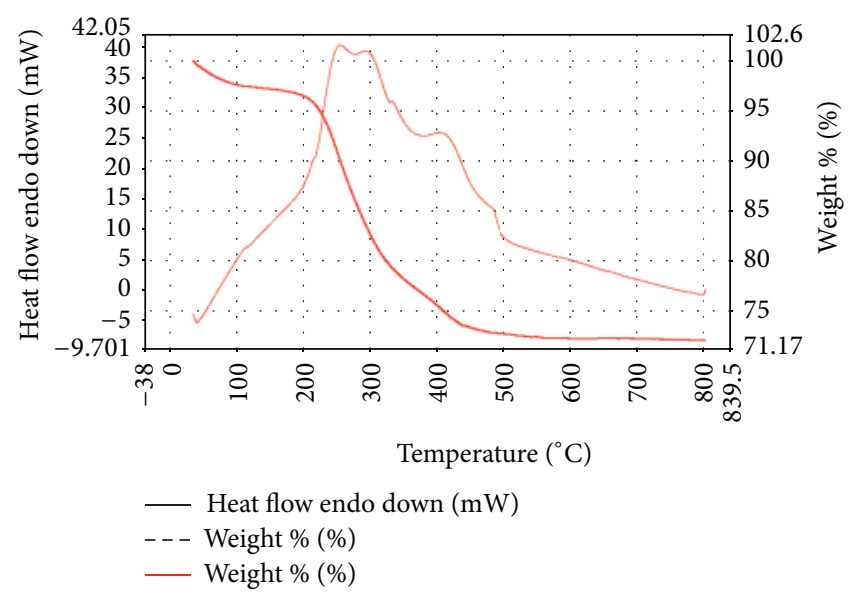

FIGURE 4: The thermogravimetric analysis (TGA) of CS-MHAP.

in two stages. The first weight loss was $3.052 \%$ indicating that mass of water or volatile compounds entrapped in prepared composite with temperatures from 35 to $175^{\circ} \mathrm{C}$. Additionally, an endothermic peak could be seen from the DSC curve. The weight loss in the second stage from 175 to $800^{\circ} \mathrm{C}$ was $25 \%$. This was mainly due to the decomposition of chitosan and an obvious peak was observed in DSC curve. Therefore, the residual compounds of prepared composite after heating at $800^{\circ} \mathrm{C}$ are $\mathrm{Fe}_{3} \mathrm{O}_{4}$ and hydroxyapatite nanoparticles $(72 \%$ weight of CS-MHAP) due to their high melting points (over $\left.1500^{\circ} \mathrm{C}\right)$.

Hysteresis loops of $\mathrm{Fe}_{3} \mathrm{O}_{4}$ and CS-MHAP were shown in Figure 5. The magnetite $\left(\mathrm{Fe}_{3} \mathrm{O}_{4}\right)$ had saturated magnetization about $44.8 \mathrm{emu} / \mathrm{g}$. However, the saturated magnetization of CS-MHAP was decreased to $3.1 \mathrm{emu} / \mathrm{g}$. The results showed that saturated magnetization of $\mathrm{Fe}_{3} \mathrm{O}_{4}$ is much higher than that of CS-MHAP due to the influence of chitosan content and dispersion of $\mathrm{Fe}_{3} \mathrm{O}_{4}$ in a large number of hydroxyapatite nanoparticles in the composite MHAP. However, magnetic composite adsorbents could be quickly collected by applying 


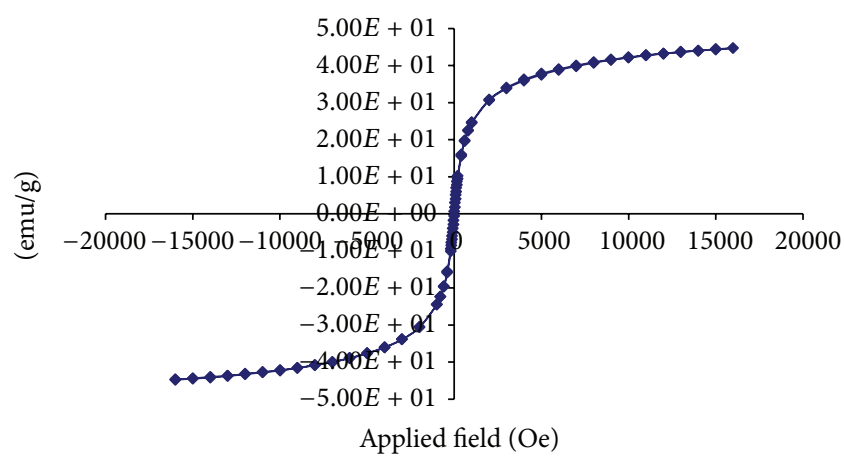

(a) $\mathrm{Fe}_{3} \mathrm{O}_{4}$

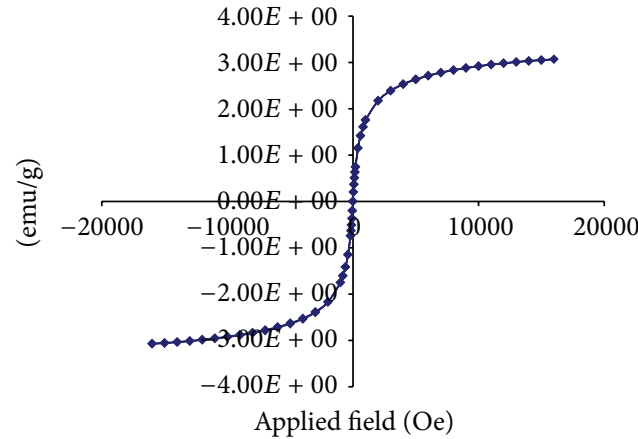

(b) CS-MHAP

FIgURE 5: Magnetization curves of (a) $\mathrm{Fe}_{3} \mathrm{O}_{4}$ and (b) CS-MHAP.

an external magnet after adsorption. Additionally, the result indicates that saturated magnetization CS-MHAP could be expediently adjusted by changing additive dosage of chitosan, hydroxyapatite, and $\mathrm{Fe}_{3} \mathrm{O}_{4}$ nanoparticles.

\subsection{Adsorption of RB19 Dye}

3.2.1. Effect of Contact Time and Initial Concentration. Figure 6 showed the effect of contact time and initial concentrations on the adsorption capacities of RB19 onto CSMHAP. As can be seen, when the time increased from 10 to $240 \mathrm{~min}$, the adsorption capacity of RB19 was directly proportional to the contact time. Moreover, the adsorptive process reached equilibrium at $240 \mathrm{~min}$ for concentration of $150 \mathrm{ppm}$ and decreased with decreasing initial concentrations of dye $(60 \mathrm{~min}$ for concentration of 50 and $75 \mathrm{ppm}$ and $120 \mathrm{~min}$ for $100 \mathrm{ppm}$ ). Additionally, an increase in the initial dye concentration leads to an increase in the adsorption capacity of the dye onto CS-MHAP. The adsorption efficiency decreased gradually with an increase of dye concentration. Particularly, adsorption efficiency was $93 \%$ at concentration of $50 \mathrm{ppm}$ and decreased to $91.2,90.5$, and $84 \%$ for concentrations of 75, 100, and $150 \mathrm{ppm}$, respectively (Figure 7). These results confirmed that initial dye concentrations played an important role in the adsorption of organic dyes onto the CS-MHAP. The adsorption efficiency increased with increase in the initial dye concentration. This may explain due to the increase in the driving force of the concentration gradient.

3.2.2. Effect of $p H$ Solution. The effect of initial $\mathrm{pH}$ on adsorption capacity of RB19 onto CS-MHAP was studied at different $\mathrm{pH}$ ranging from 6 to 12 . The results were represented in Figure 8 . These results expressed that the adsorption capacity of RB19 increased with the decreasing of $\mathrm{pH}$. As seen, it is clear that the adsorption capacity at acidic solution (at $\mathrm{pH}=$ $6 ; q_{o}=25.386 \mathrm{mg} / \mathrm{g}$ ) is higher than those of basic solutions (at $\mathrm{pH}=8,10$, and $12 ; q_{o}=24.3,18.5$, and $15.1 \mathrm{mg} / \mathrm{g}$, resp.). This is due to the fact that at a lower $\mathrm{pH}$ the $-\mathrm{NH}_{2}$ groups of chitosan were protonated by $\mathrm{H}_{3} \mathrm{O}^{+}$ions in acidic solution which yields positively charged $-\mathrm{NH}_{3}^{+}$groups. Moreover, the RB19 is an anionic dye, which can be adsorbed on positively charged surface of CS-MHAP. On the contrary, when the

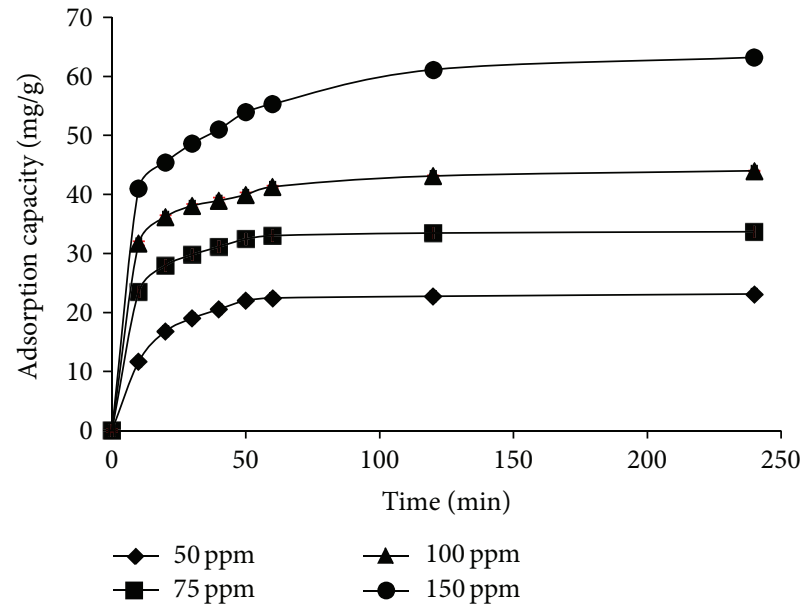

FIGURE 6: Adsorption kinetics of RB19 onto CS-MHAP at different initial concentrations (0.1 g CS-MHAP; solution volume: $50 \mathrm{~mL}$ and $\mathrm{pH}=6)$.

$\mathrm{pH}$ of the solution increases, high $\mathrm{OH}$ ions accumulate on the adsorbent surface. Therefore, electrostatic interaction between negatively charged adsorbent surface and anionic dye molecule decreases the adsorption of dye molecular on the surface of CS-MHAP. Moreover, the adsorption capacity at $\mathrm{pH} 4$ was lower than that of $\mathrm{pH} 6$ due to the solubility of chitosan shells in acidic media [17].

3.2.3. Effect of CS-MHAP Dosage. Adsorption dosage is an important parameter because it determines the capacity of an adsorbent for a given initial concentration of adsorbate. As shown in Figure 9, the amount of RB19 adsorbed increased rapidly with the increasing of CS-MHAP amount at first $50 \mathrm{~min}$ and then it increased slowly from 50 to $120 \mathrm{~min}$. The adsorption capacity reached a maximum equilibrium at $240 \mathrm{~min}$. Additionally, it was found that the adsorption capacity rises with an increase in the weight of adsorbents; this is because the adsorption capacity depends on the external surface of the adsorbent increases with a large mass. The adsorption capacity of RB19 dye onto CS-MHAP is $60.9 \mathrm{mg} / \mathrm{g}$ for $0.1 \mathrm{~g}$ of CS-MHAP and decreased to $23.1 \mathrm{mg} / \mathrm{g}$ for $0.025 \mathrm{~g}$ of CS-MHAP (Figure 9). 


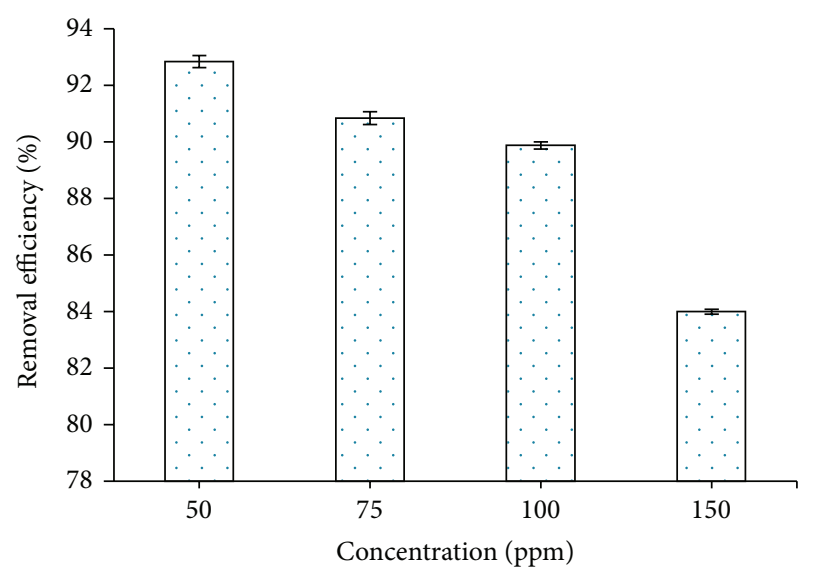

Figure 7: Adsorption efficiency of CS-MHAP at different concentrations of RB19 (0.1 g CS-MHAP; solution volume: $50 \mathrm{~mL}$ and $\mathrm{pH}=$ $6)$.

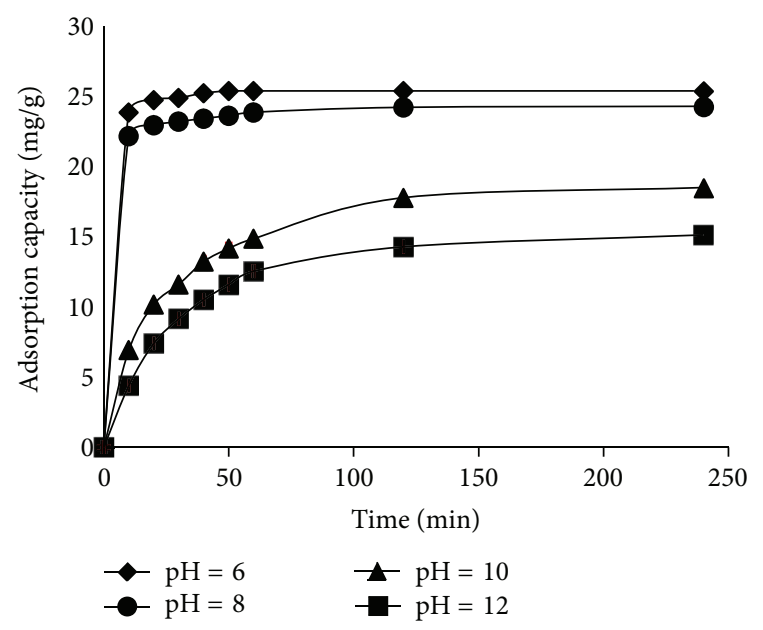

FIGURE 8: Effect of initial $\mathrm{pH}$ on the adsorption of RB19 onto CSMHAP (0.1 g CS-MHAP; solution volume: $50 \mathrm{~mL}$ and concentration of $50 \mathrm{ppm})$.

As shown in Figure 10, the adsorption of RB19 at $592 \mathrm{~nm}$ decreased with increasing the MHAP amount. The disappearance of adsorption at $592 \mathrm{~nm}$ was observed at dosage of $0.1 \mathrm{~g}$; this confirmed that most of RB19 was adsorbed under experiment condition.

\subsection{Adsorption of $\mathrm{Ni}^{2+}$ Ions}

3.3.1. Effect of Contact Time and Initial Concentration. The effect of contact time and initial concentration of $\mathrm{Ni}^{2+}$ ions was presented in Figure 11. As can be seen, adsorption capacity of $\mathrm{Ni}^{2+}$ was positively correlated with increasing $\mathrm{Ni}^{2+}$ ions concentrations from 25 to $100 \mathrm{ppm}$ and contact time before equilibrium was attained. Additionally, the results indicated that equilibrium time increased with increasing initial concentration of metal ions. At the concentration of $25 \mathrm{ppm}$ the adsorption phenomena occurred quickly and almost reached equilibrium after $180 \mathrm{~min}$ and increased to

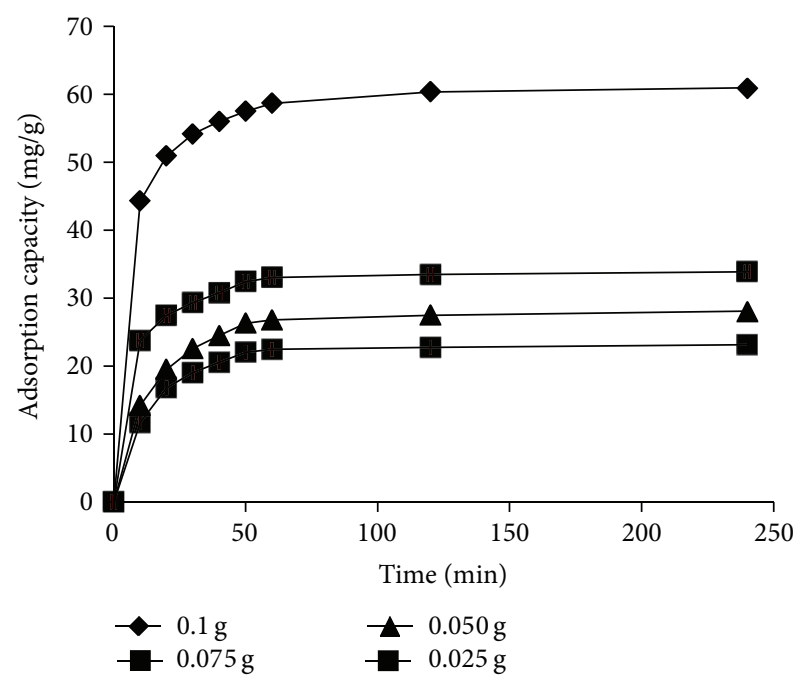

FIGURE 9: Adsorption kinetics of RB19 onto CS-MHAP at different amounts of adsorbent (solution volume: $50 \mathrm{~mL} ; \mathrm{pH}=6$ and concentration of $50 \mathrm{ppm})$.

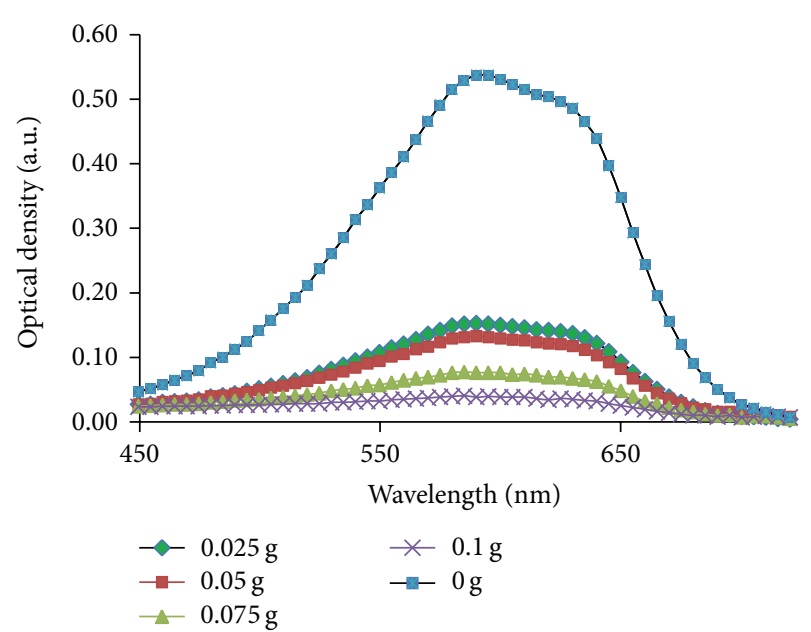

FIGURE 10: The change in absorption spectra of RB19 using various amounts of CS-MHAP (solution volume: $50 \mathrm{~mL} ; \mathrm{pH}=6$ and concentration of $50 \mathrm{ppm})$.

300 and $360 \mathrm{~min}$ for concentrations of 50 and $100 \mathrm{ppm}$, respectively. As observed, the removal efficiency was $96.5 \%$ at a concentration of $25 \mathrm{ppm}$; however, the removal efficiency decreased to $83.5 \%$ at a concentration of $100 \mathrm{ppm}$ (Figure 12). The adsorption mechanism of $\mathrm{Ni}^{2+}$ was explained by a combination of 2 processes: (1) adsorption of $\mathrm{Ni}^{2+}$ ions onto surface of chitosan by a complex reaction due to $-\mathrm{NH}_{2}$ and $-\mathrm{OH}$ groups of chitosan [29] and (2) adsorption of $\mathrm{Ni}^{2+}$ ions onto the surface of hydroxyapatite nanoparticles by exchanging with $\mathrm{Ca}^{2+}$ ions [30].

3.3.2. Effect of $p H$. As known, the $\mathrm{pH}$ affects the availability of metal ions in solutions and the metal binding sites of the adsorbent. The effect of $\mathrm{pH}$ on the removal efficiency of $\mathrm{Ni}^{2+}$ ions onto CS-MHAP was determined at the range 


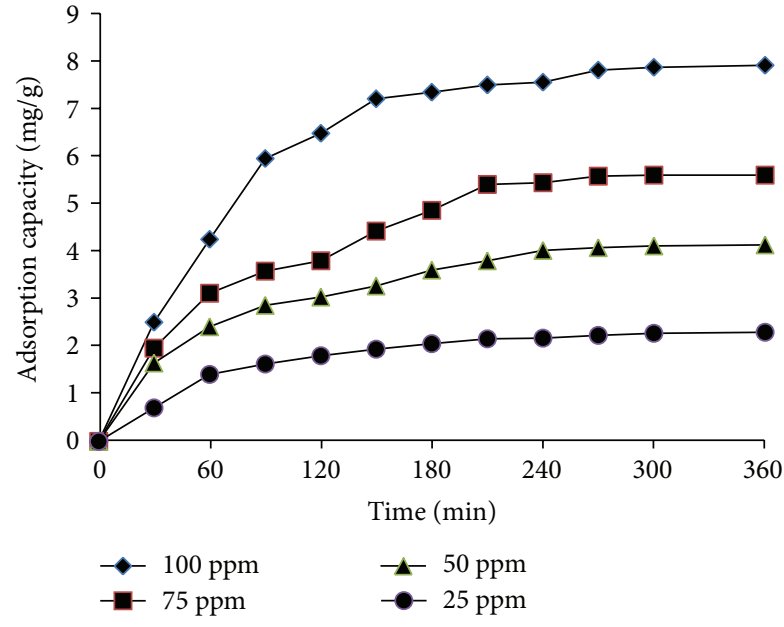

FIGURE 11: Effect of contact time on adsorption of $\mathrm{Ni}^{2+}$ ions onto CS-MHAP (0.5 g CS-MHAP; solution volume: $50 \mathrm{~mL}$ and $\mathrm{pH}=6$ ).

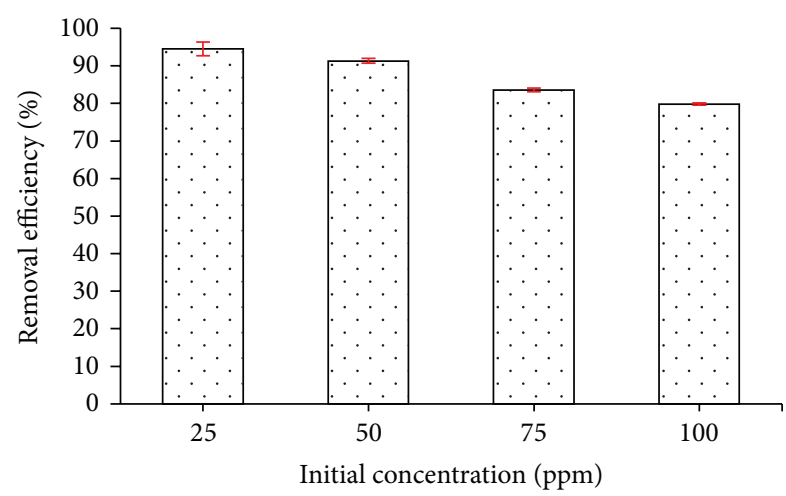

FIgURE 12: Removal efficiency of different initial $\mathrm{Ni}^{2+}$ ion concentrations onto CS-MHAP (0.5 g CS-MHAP; solution volume: $50 \mathrm{~mL}$ and $\mathrm{pH}=6$ ).

of $\mathrm{pH}$ from 4 to 7 . The removal efficiency of $\mathrm{Ni}^{2+}$ ions onto CS-MHAP decreased when the $\mathrm{pH}$ value increased from 5 to 7. It should be noted that when the $\mathrm{pH}$ value is higher than 7 , the adsorption amount decreased dramatically, which was attributed to the fact that $\mathrm{Ni}^{2+}$ ion started to precipitate leading to the reduction of $\mathrm{Ni}^{2+}$ in the solution. The removal efficiencies were $97.4,95.6$, and $91.1 \%$ for $\mathrm{pH}$ of 5,6 , and 7 , respectively (Figure 13).

3.3.3. Effect of CS-MHAP Amount. In this present study, the dependence of the adsorption capacity of $\mathrm{Ni}^{2+}$ ions onto CS-MHAP amount was investigated by varying dosage of adsorbent from 0.1 to $0.5 \mathrm{~g}$, while keeping other parameters constant (Figure 14). As the adsorption phenomena of RB19, the adsorption capacity of $\mathrm{Ni}^{2+}$ ions onto CS-MHAP augmented rapidly and the time to reach equilibrium was more quick when dosage of adsorbents increased. Particularly, at equilibrium time, the adsorption capacity of $\mathrm{Ni}^{2+}$ ions was $4.3 \mathrm{mg} / \mathrm{g}$ with $0.5 \mathrm{~g}$ dosage of the adsorbent and decreased to $1.4 \mathrm{mg} / \mathrm{g}$ for $0.1 \mathrm{~g}$ CS-MHAP. Additionally, the removal efficiencies were increased from 19.8 to $91.2 \%$ when the dose of adsorbents was increased from 0.1 to $0.5 \mathrm{~g}$. This could be

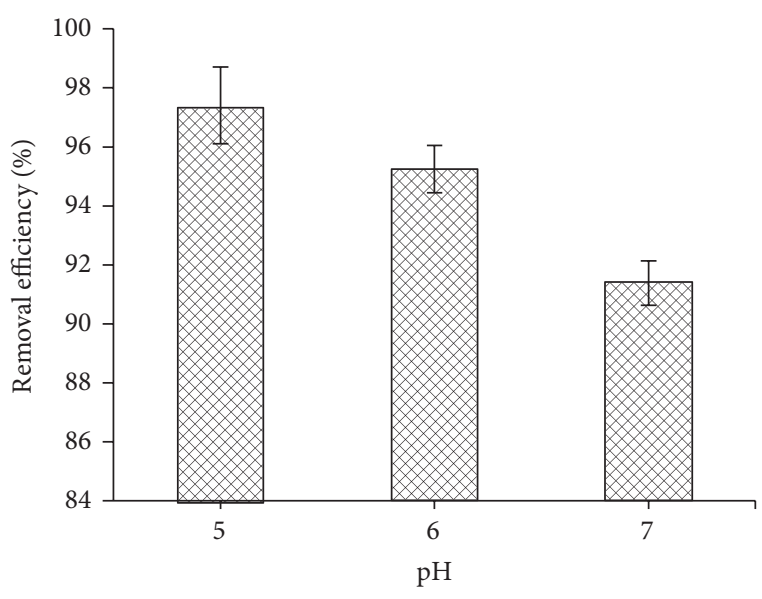

FIGURE 13: The effect of $\mathrm{pH}$ on adsorption capacity of $\mathrm{Ni}^{2+}$ ions onto CS-MHAP (0.5 g CS-MHAP; solution volume: $50 \mathrm{~mL}$ and concentration of $50 \mathrm{ppm})$.

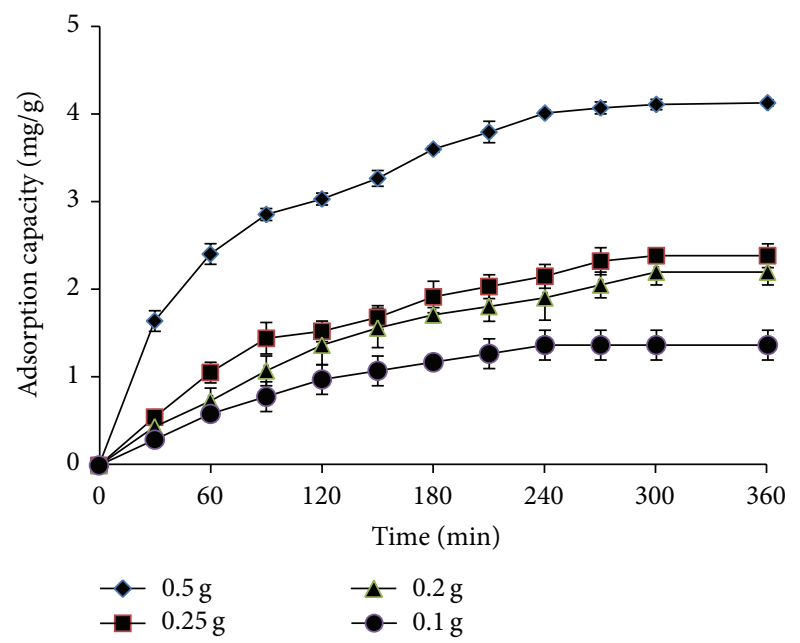

FIGURE 14: The relationship between adsorption capacity of $\mathrm{Ni}^{2+}$ ions and CS-MHAP dosage (solution volume: $50 \mathrm{~mL} ; \mathrm{pH}=5$ and concentration of $50 \mathrm{ppm}$ ).

explained by the fact that the higher dose of adsorbents in the solution, the greater availability of exchangeable sites for the ions.

3.4. Comparative Adsorption. The variances of adsorption capacity of RB 19 and $\mathrm{Ni}^{2+}$ ions for different adsorbents were shown in Figures 15 and 16. As a result, CS-MHAP represented the most effectiveness for adsorption of metal ions and dye among the various adsorbents (chitosan and magnetic hydroxyapatite nanoparticles). The results indicated that combination of CS and HA into composite leads to adsorption capacity of CS-MHAP which remarkably improved. The adsorption amounts for MHAP, chitosan, and CS-MHAP were $6.2,16.4$, and $26.4 \mathrm{mg} / \mathrm{g}$, respectively. The adsorption capacity of $\mathrm{Ni}^{2+}$ ions CS-MHAP was $4.3 \mathrm{mg} / \mathrm{g}$ and decreased to 2.5 and $1.4 \mathrm{mg} / \mathrm{g}$ for MHAP and chitosan, respectively. In addition, the magnetic composite adsorbents also showed the magnetic property and significant improvement of the separability from aqueous solutions after adsorption. 


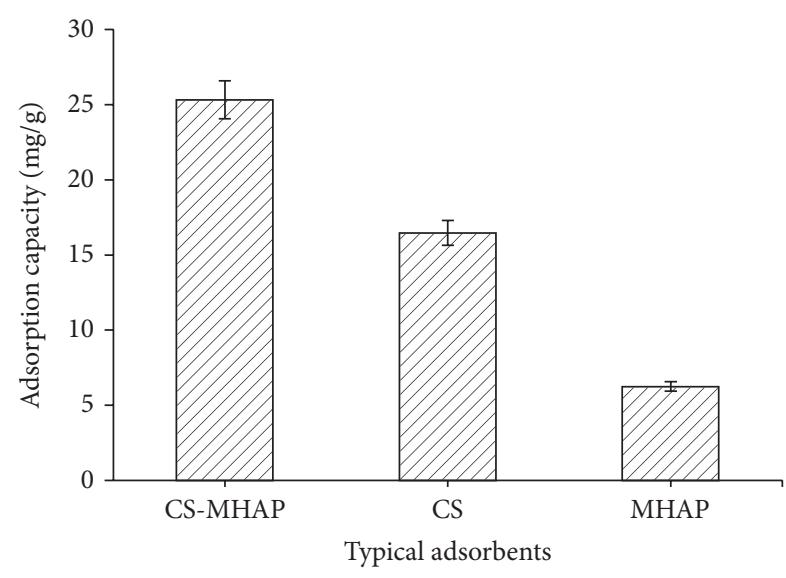

FIGURE 15: The adsorption of typical adsorbents for adsorption of RB19 (solution volume: $50 \mathrm{~mL} ; \mathrm{pH}=6$ and concentration of $50 \mathrm{ppm})$.

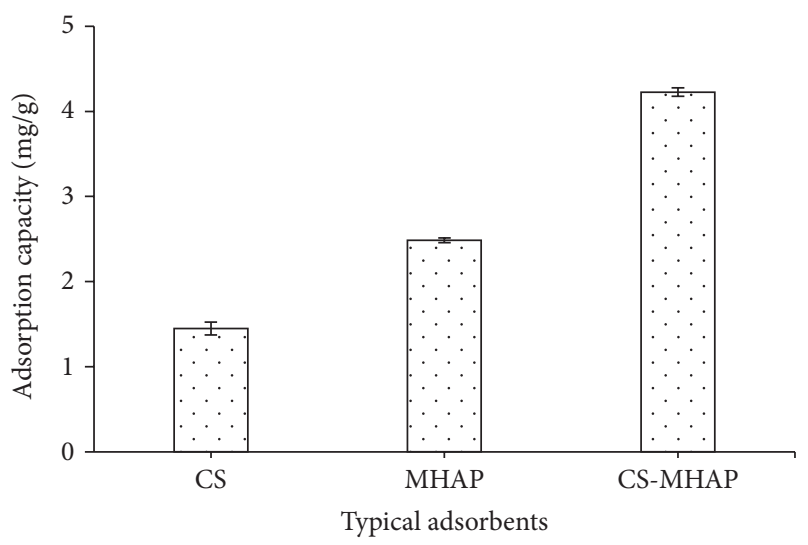

FIGURE 16: Adsorption comparison of typical adsorbents for adsorption of $\mathrm{Ni}^{2+}$ ions (solution volume: $50 \mathrm{~mL} ; \mathrm{pH}=5$ and concentration of $50 \mathrm{ppm})$.

\section{Conclusions}

In this present study, a novel magnetic composite of chitosan and hydroxyapatite nanoparticles was successfully prepared by simple precipitation method. Then, the prepared composite was characterized by XRD, FT-IR, TGA, SEM, and VSM. The adsorption of heavy metals and dyes onto the prepared magnetic composite was investigated in a batch experiment. The various parameters such as contact time, initial concentrations, $\mathrm{pH}$, and adsorbent dosage showed significantly effects on the adsorption capacity of $\mathrm{Ni}^{2+}$ ions and dye. Maximum removals of $\mathrm{RB} 19$ and $\mathrm{Ni}^{2+}$ ions onto CSMHAP were at $\mathrm{pH} 5.0$ and $\mathrm{pH}$ 6, respectively.

\section{Conflict of Interests}

The authors declare that there is no conflict of interests regarding the publication of this paper.

\section{References}

[1] L. Järup, "Hazards of heavy metal contamination," British Medical Bulletin, vol. 68, no. 1, pp. 167-182, 2003.

[2] S. A. Al Bakheet, I. M. Attafi, Z. H. Maayah, A. R. Abd-Allah, Y. A. Asiri, and H. M. Korashy, "Effect of long-term human exposure to environmental heavy metals on the expression of detoxification and DNA repair genes," Environmental Pollution, vol. 181, pp. 226-232, 2013.

[3] P. R. Gogate and A. B. Pandit, "A review of imperative technologies for wastewater treatment II: hybrid methods," Advances in Environmental Research, vol. 8, no. 3-4, pp. 553-597, 2004.

[4] V. Vimonses, S. Lei, B. Jin, C. W. K. Chow, and C. Saint, "Kinetic study and equilibrium isotherm analysis of Congo Red adsorption by clay materials," Chemical Engineering Journal, vol. 148, no. 2-3, pp. 354-364, 2009.

[5] I. Oller, S. Malato, and J. A. Sánchez-Pérez, "Combination of advanced oxidation processes and biological treatments for wastewater decontamination-a review," Science of the Total Environment, vol. 409, no. 20, pp. 4141-4166, 2011.

[6] L. L. Blackall, G. R. Crocetti, A. M. Saunders, and P. L. Bond, "A review and update of the microbiology of enhanced biological phosphorus removal in wastewater treatment plants," Antonie van Leeuwenhoek, vol. 81, no. 1-4, pp. 681-691, 2002.

[7] T. Pavón-Silva, V. Pacheco-Salazar, J. Carlos Sánchez-Meza, G. Roa-Morales, and A. Colín-Cruz, "Physicochemical and biological combined treatment applied to a food industry wastewater for reuse," Journal of Environmental Science and Health A, vol. 44, no. 1, pp. 108-115, 2009.

[8] G. Chen, "Electrochemical technologies in wastewater treatment," Separation and Purification Technology, vol. 38, no. 1, pp. 11-41, 2004.

[9] F. A. Pavan, A. C. Mazzocato, and Y. Gushikem, "Removal of methylene blue dye from aqueous solutions by adsorption using yellow passion fruit peel as adsorbent," Bioresource Technology, vol. 99, no. 8, pp. 3162-3165, 2008.

[10] S. Lodha, A. Jain, and P. B. Punjabi, "A novel route for waste water treatment: photocatalytic degradation of rhodamine B," Arabian Journal of Chemistry, vol. 4, no. 4, pp. 383-387, 2011.

[11] G. M. Walker and L. R. Weatherley, "Biological activated carbon treatment of industrial wastewater in stirred tank reactors," Chemical Engineering Journal, vol. 75, no. 3, pp. 201-206, 1999.

[12] Y. Ma, N. Gao, W. Chu, and C. Li, "Removal of phenol by powdered activated carbon adsorption," Frontiers of Environmental Science \& Engineering, vol. 7, no. 2, pp. 158-165, 2013.

[13] I. Aranaz, M. Mengíbar, R. Harris et al., "Functional characterization of chitin and chitosan," Current Chemical Biology, vol. 3, no. 2, pp. 203-230, 2009.

[14] R. Jayakumar, M. Prabaharan, P. T. S. Kumar, S. V. Nair, and H. Tamura, "Biomaterials based on chitin and chitosan in wound dressing applications," Biotechnology Advances, vol. 29, no. 3, pp. 322-337, 2011.

[15] V. C. Nguyen, V. B. Nguyen, and M.-F. Hsieh, "Curcuminloaded chitosan/gelatin composite sponge for wound healing application," International Journal of Polymer Science, vol. 2013, Article ID 106570, 7 pages, 2013.

[16] M.-S. Chiou, P.-Y. Ho, and H.-Y. Li, "Adsorption of anionic dyes in acid solutions using chemically cross-linked chitosan beads," Dyes and Pigments, vol. 60, no. 1, pp. 69-84, 2004. 
[17] N. Sakkayawong, P. Thiravetyan, and W. Nakbanpote, "Adsorption mechanism of synthetic reactive dye wastewater by chitosan," Journal of Colloid and Interface Science, vol. 286, no. 1, pp. 36-42, 2005.

[18] J. Fan, L. Bi, T. Wu et al., "A combined chitosan/nano-size hydroxyapatite system for the controlled release of icariin," Journal of Materials Science, vol. 23, no. 2, pp. 399-407, 2012.

[19] L. Chen, J. Hu, X. Shen, and H. Tong, "Synthesis and characterization of chitosan-multiwalled carbon nanotubes/hydroxyapatite nanocomposites for bone tissue engineering," Journal of Materials Science, vol. 24, no. 8, pp. 1843-1851, 2013.

[20] M. R. Gandhi, G. N. Kousalya, and S. Meenakshi, "Removal of copper(II) using chitin/chitosan nano-hydroxyapatite composite," International Journal of Biological Macromolecules, vol. 48, no. 1, pp. 119-124, 2011.

[21] G. N. Kousalya, M. R. Gandhi, C. S. Sundaram, and S. Meenakshi, "Synthesis of nano-hydroxyapatite chitin/chitosan hybrid biocomposites for the removal of Fe(III)," Carbohydrate Polymers, vol. 82, no. 3, pp. 594-599, 2010.

[22] Y. Feng, J.-L. Gong, G.-M. Zeng et al., "Adsorption of Cd (II) and Zn (II) from aqueous solutions using magnetic hydroxyapatite nanoparticles as adsorbents," Chemical Engineering Journal, vol. 162, no. 2, pp. 487-494, 2010.

[23] N. R. Kildeeva, P. A. Perminov, L. V. Vladimirov, V. V. Novikov, and S. N. Mikhailov, "About mechanism of chitosan crosslinking with glutaraldehyde," Russian Journal of Bioorganic Chemistry, vol. 35, no. 3, pp. 360-369, 2009.

[24] H. Hu, J. H. Xin, H. Hu, A. Chan, and L. He, "Glutaraldehydechitosan and poly (vinyl alcohol) blends, and fluorescence of their nano-silica composite films," Carbohydrate Polymers, vol. 91, no. 1, pp. 305-313, 2012.

[25] J. He, S. Hong, L. Zhang, F. Gan, and Y.-S. Ho, "Equilibrium and thermodynamic parameters of adsorption of methylene blue onto rectorite," Fresenius Environmental Bulletin, vol. 19, no. 11, pp. 2651-2656, 2010.

[26] American Water Works Association and American Public Health Association, Standard Methods for Examination of Water \& Wastewater, American Public Health Association, Washington, DC, USA, 20th edition, 1999.

[27] H. Li, C. -R. Zhou, M. -Y. Zhu, J. -H. Tian, and J. -H. Rong, "Preparation and characterization of homogeneous hydroxyapatite/chitosan composite Scaffolds via in-situ hydration," Journal of Biomaterials and Nanobiotechnology, vol. 1, no. 1, pp. 42-49, 2010.

[28] S. Mondal, B. Mondal, A. Dey, and S. S. Mukhopadhyay, "Studies on processing and characterization of hydroxyapatite biomaterials from different bio wastes," Journal of Minerals \& Materials Characterization, vol. 11, no. 1, pp. 55-67, 2012.

[29] R. Schmuhl, H. M. Krieg, and K. Keizer, "Adsorption of $\mathrm{Cu}$ (II) and $\mathrm{Cr}(\mathrm{VI})$ ions by chitosan: kinetics and equilibrium studies," Water SA, vol. 27, no. 1, pp. 1-8, 2001.

[30] D. Liao, W. Zheng, X. Li et al., "Removal of lead(II) from aqueous solutions using carbonate hydroxyapatite extracted from eggshell waste," Journal of Hazardous Materials, vol. 177, no. 1-3, pp. 126-130, 2010. 

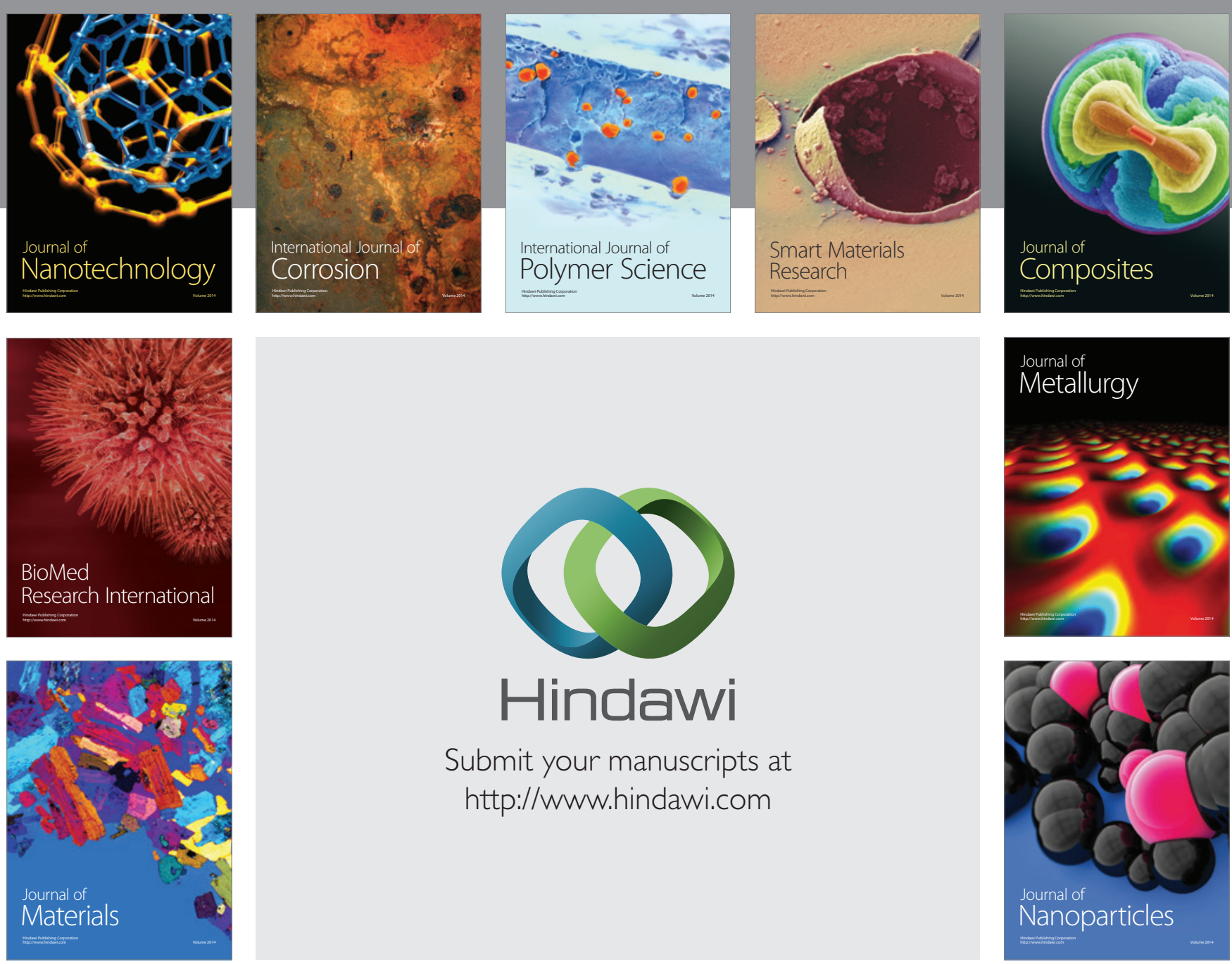

Submit your manuscripts at http://www.hindawi.com
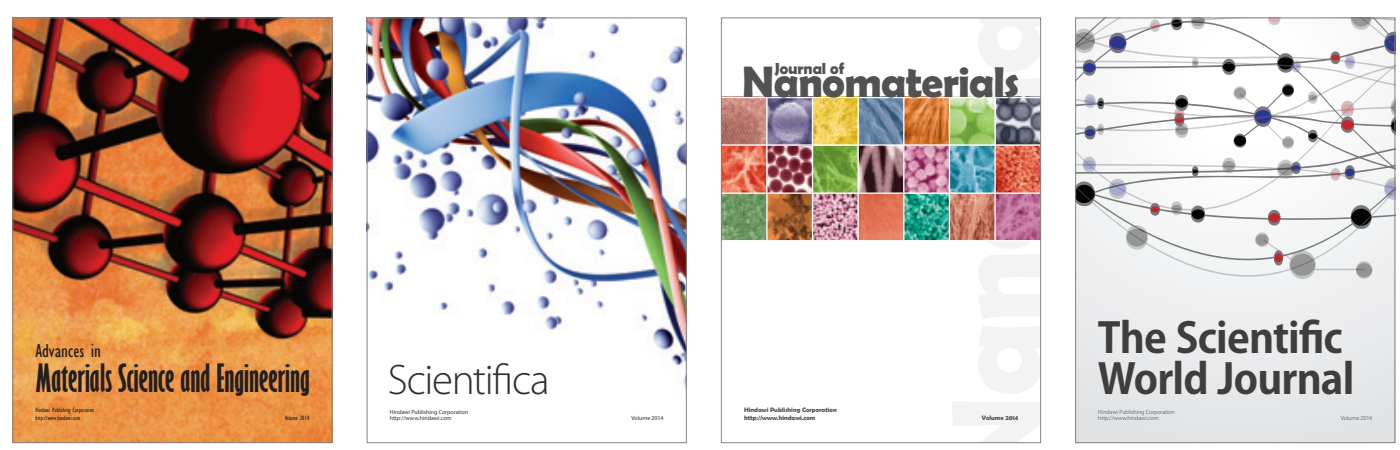

\section{The Scientific World Journal}
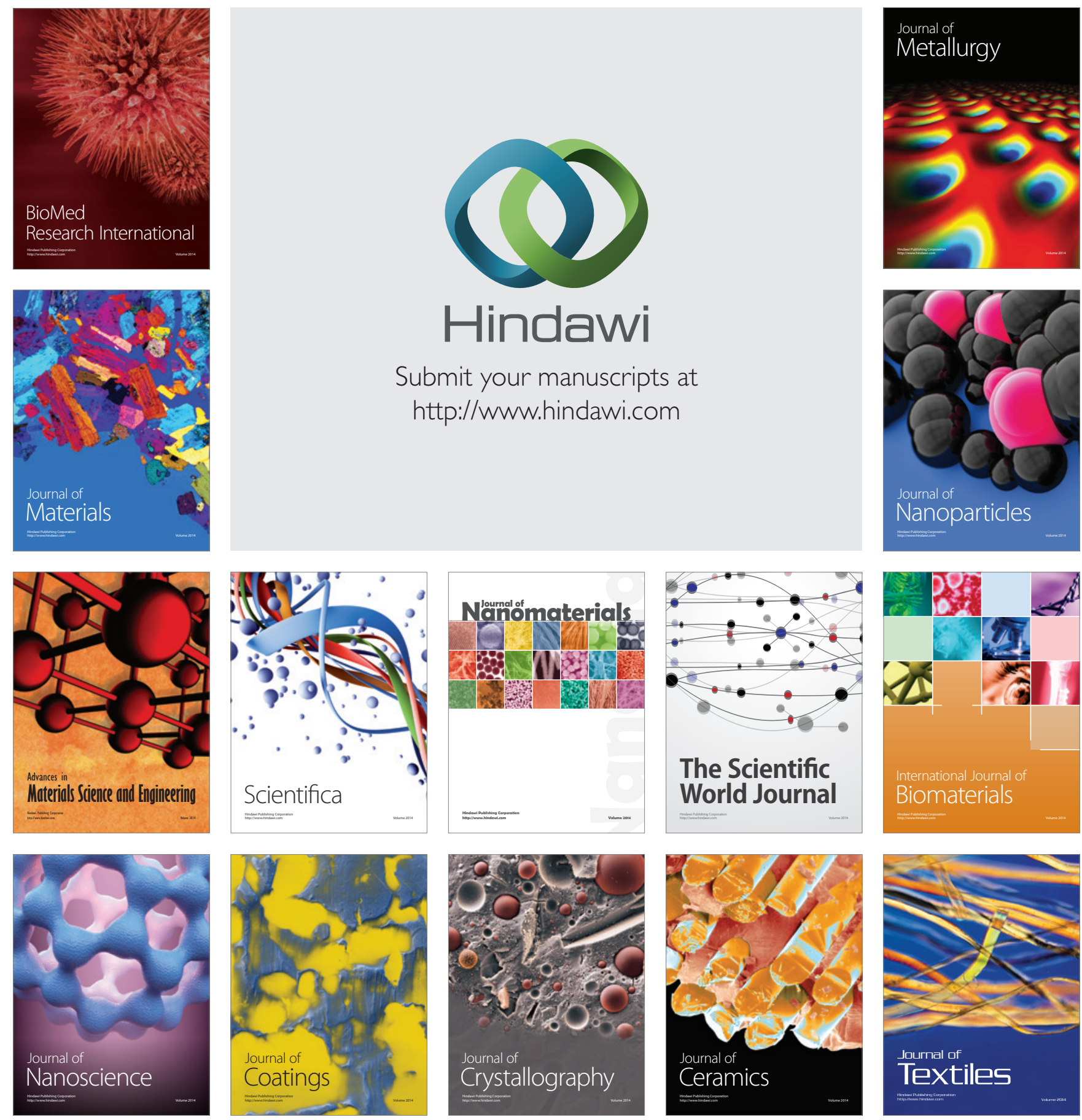